ANNA TRELA

ORCID: 0000-0002-2014-5579

Uniwersytet im. Adama Mickiewicza w Poznaniu annatrela@poczta.onet.pl

\title{
Koncepcja ciągu działań prawnych w publicznym prawie gospodarczym (wybrane zagadnienia)
}

\begin{abstract}
Abstrakt: Autorka dokonuje charakterystyki koncepcji ciągu działań prawnych, wskazując jej podstawowe cechy oraz zastosowanie w naukach prawnych. Koncepcję tę uzupełnia o „układ działań realizujących” oraz ,ideę działań złożonych w administracji”, uznając, że tworzą one spójną koncepcję, której odzwierciedleniem jest zespół działań podejmowanych na gruncie publicznego prawa gospodarczego.
\end{abstract}

Słowa kluczowe: ciąg działań prawnych, prawne formy działania, działania złożone, organizacja usług, działania wzajemnie powiązane.

\section{Wprowadzenie}

Specyfika stosunków prawnych i ich wzajemnych powiązań w procesie gospodarowania wykazuje, że tradycyjne metody klasyfikacji form działania administracji okazują się niewystarczające. Gwałtowny rozwój stosunków społecznych po 1989 roku oraz nowe formy gospodarowania, jak stwierdziła Teresa Rabska, „rozsadziły tradycyjne ramy” znanego dotychczas porządku prawnego ${ }^{1}$. Zdaniem badaczki „rozwój publicznego prawa gospodarczego doprowadził nie tylko do ukształtowania własnej sieci form prawnych działania administracji publicznej, ale przesądził również o odrębności i istocie publicznego prawa gospodarczego"2.

1 T. Rabska, Działania administracji publicznej w świetle wspótczesnej koncepcji publicznego prawa gospodarczego, [w:] Instrumenty i formy prawne działania administracji gospodarczej, red. B. Popowska, K. Kokocińska, Poznań 2009, s. 31.

2 Ibidem, s. 33-34. 
Co ciekawe, autorka zwraca uwagę, że obok typowych działan indywidualnych o charakterze władczym coraz częściej pojawiają się akty o charakterze ogólnym, wskazujące kierunki działalności (informacje, strategie, plany) ${ }^{3}$. Znamienne dla publicznego prawa gospodarczego jest to, że przepisy prawne wprowadzają coraz nowe formy działania, ustalając nowe nazwy, treści, a także szczególne wymogi proceduralne ${ }^{4}$. Wyjątkowy sposób regulacji stosunków prawnych w obrębie publicznego prawa gospodarczego, to jest na linii państwo-przedsiębiorca, nakazuje traktować je w sposób systemowy (całościowy). Analiza poszczególnych działań administracji charakteryzowanych odrębnie w wielu wypadkach bywa bowiem zabiegiem uproszczonym i nieuwzględniającym ich złożoności ${ }^{5}$.

Spojrzenie systemowe na działania administracji wzajemnie z sobą powiązane i uwarunkowane nie jest zabiegiem nowatorskim - ma długą tradycję w nauce prawa administracyjnego. Już w latach sześćdziesiątych ubiegłego wieku zgłoszono koncepcję ciągu działań prawnych, której autorem był Adam Chełmoński, oraz koncepcję działań złożonych administracji autorstwa Tadeusza Kuty i Adama Błasia.

Koncepcje te, odnoszące się wprawdzie do działań administracji podejmowanych w innym ustroju społeczno-gospodarczym, mają charakter uniwersalny i śmiało można powiedzieć, że były i nadal są przełomowe. Ich znaczenia nie można bowiem nie doceniać współcześnie, kiedy publiczne prawo gospodarcze ulega ciągłym zmianom podporządkowanym realizacji nowych zadań i funkcji. Sprawia to, że na tę gałąź prawa składają się przeważnie normy prawne, które zarówno w warstwie ustrojowej, jak i materialnoprawnej oraz proceduralnej są niezwykle złożone. Wieloszczeblowość struktury normowania poszczególnych instytucji oraz treść norm prawnych nakazuje w dalszym ciągu powracać do koncepcji, dzięki którym można ukazać wielopoziomowość i różnorodność działań powiązanych występujących w publicznym prawie gospodarczym.

\section{Koncepcje ciągu działań prawnych oraz działań złożonych}

Adam Chełmoński ${ }^{6}$ zauważył, że odrębność prawa gospodarki państwowej jest tak znamienna, że nie można dokonywać badań nad stosunkami prawnymi zachodzącymi w jego obszarze z wykorzystaniem tradycyjnych narzędzi zaczerp-

3 Ibidem, s. 31.

${ }^{4}$ Ibidem, s. 32.

5 K. Sobczak, Płaszczyzny zależności między władza publiczna i gospodarka, [w:] Prawo administracyjne w okresie transformacji ustrojowej, red. E. Knosala, A. Matan, G. Łaszczyca, Kraków 1999, s. 509-510.

6 A. Chełmoński, Przedsiębiorstwo państwowe wobec organów zwierzchnich, Wrocław 1966; T. Kuta, Aspekty prawne działań administracji publicznej w organizowaniu ustug, Wrocław 1969. 
niętych z prawa administracyjnego ${ }^{7}$. Zdaniem autora system prawny w gospodarce państwowej nastawiony jest nie na regulowanie działań jednostkowych, lecz całych zespołów takich działań ${ }^{8}$. Wobec takich założeń Adam Chełmoński uznał, że wskazane byłoby włączenie do zasobu pojęć prawnych terminu „ciąg działań” oraz że pojęcie to mogłoby być przydatne wszędzie tam, gdzie dotychczasowa terminologia jest niewystarczająca. Jak słusznie stwierdził badacz, całe życie prawne gospodarki tworzy jeden obszerny ciąg działań, dlatego też wyodrębnił główne cechy ciągów działań, do których zaliczył: wspólny cel i niemożliwość osiągnięcia celu przez oddzielne zastosowanie działań. Działania należące do ciągu stopniowo kształtują bowiem sytuację prawną podmiotów, przy czym stopień samodzielności poszczególnych działań może być różny. W ramach ciągu autor wyodrębnił także działania podmiotów administrowanych (zarządzanych), dopełniających działania organów administracji gospodarczej, oraz wskazał, że ciągi działań występują w różnych relacjach podmiotowych oraz — co istotne — działania składające się na ciąg rozkładają się w czasie9.

Poczynione rozważania na temat koncepcji ciągu działań pozwoliły Adamowi Chełmońskiemu wyróżnić ciągi zmierzające do jednorazowego celu (tak zwane ciągi zamknięte niepowtarzalne); ciągi, których celem jest wprawdzie realizacja celu jednorazowego, ale powtarzalnego, na przykład w ramach planowania (ciąg zamknięty powtarzalny); oraz ciągi otwarte, w których cel nie jest umiejscowiony $\mathrm{w}$ czasie $^{10}$. Badacz ostatecznie stwierdził, że

ciąg działań to grupa działań połączonych wspólnym celem faktycznym i prawnym, którego nie da się osiągnąć jednym poszczególnym działaniem; działania wchodzące w skład ciągu nie mają charakteru konkludentnego i są w pewien sposób powiązane ${ }^{11}$.

Przechodząc do koncepcji działań złożonych Tadeusza Kuty, moglibyśmy dzisiaj śmiało powiedzieć, że współcześnie wpisuje się ona bezpośrednio w działania podejmowane $\mathrm{w}$ ramach usług komunalnych. Jej istota polega na odgraniczeniu działań organizujących usługi od świadczenia usług. Działania organizujące przejawiają bowiem inny charakter prawny oraz odgrywają odmienną rolę $\mathrm{w}$ „,całości realizacji usługi” ${ }^{2}$. Są to działania podejmowane w różnych formach prawnych, a także działania faktyczne, które nie mają charakteru jednorazowego i są od siebie zależne.

Z kolei Adam Błaś, podejmując badania nad koncepcją działań złożonych, zauważył, że coraz częściej w życiu społeczno-gospodarczym dają o sobie znać zjawiska, w ramach których niektóre działania nie są przez prawo określone, choć

${ }^{7}$ A. Chełmoński, Ciag działań w gospodarce jako przedmiot badań - propozycje metodologiczne, Wrocław 1972, s. 19.

8 Ibidem, s. 20.

9 Ibidem, s. 21.

10 Ibidem, s. 22.

11 Ibidem.

12 T. Kuta, op. cit., s. 31. 
są one w pewien sposób powiązane i współzależne od działań określonych przez prawo $^{13}$. Odnosząc się do działalności administracji nakierowanej na realizację zadania, autor wprowadził pojęcie ,układ działań realizujących”" ${ }^{14}$, w ramach którego proces administrowania nie tworzy splotu przypadkowych działań — „Jest to uświadomiony i zaplanowany proces organizowania $\mathrm{w}$ określonym celowym układzie działań realizujących" ${ }^{15}$. Układ ten może być przy tym w całości ujęty w normy prawne, lecz możliwe jest także tworzenie układów działań, które nie są determinowane normami prawnymi, a raczej zasadami organizacji, w ramach której należy uwzględniać „układy najbardziej racjonalnych relacji i powiązań służących prawidłowej realizacji zadań" ${ }^{\prime 6}$. Według Adama Błasia działania złożone administracji powinny być rozumiane jako ciąg działań prawnych i faktycznych, strukturalnie uporządkowanych według takich składników organizacji, jak: planowanie, kierownictwo, koordynacja, kontrola, nadzór czy system informacji ${ }^{17}$.

Warto podkreślić, że w nowych warunkach społeczno-gospodarczych Tadeusz Kuta kontynuował badania nad koncepcją działań złożonych. Wyodrębniając trzy podstawowe funkcje współczesnej administracji, to jest funkcję reglamentacyjno-porządkową, wykonawczą oraz organizującą, wskazał na powiązania istniejące między funkcją wykonawczą a organizującą ${ }^{18}$. Ta druga czerpie swą moc z pierwszej, uwarunkowanej wolą ustawodawcy. Zdaniem autora

Ustawodawca, wydając ustawy ramowe, daje administracji umocowanie do twórczego, samodzielnego, ale i odpowiedzialnego wypełniania tych ram działania. [...] Działania organizujące są działaniami złożonymi z różnych jednostkowych form prawnych i pozaprawnych oraz ułożone w pewien logicznie uporządkowany ciąg, który zależny jest od wartości i celów objętych nią funkcji organizującej, jak i od struktury organizacyjnej administracji publicznej, w ramach której są one realizowane ${ }^{19}$.

Zdaniem Tadeusza Kuty w każdej strukturze działań organizujących można wyróżnić fazę koncepcyjno-przygotowawczą, fazę uchwalenia opracowanej koncepcji oraz fazę realizacyjną. Według autora najbardziej charakterystyczne dla działań organizujących jest to, że występują w pewnych ciągach tworzących całości, na które składają się działania prawne i pozaprawne. Typowo nowymi działaniami w ramach tych ciągów są: współdziałanie, koordynacja, kooperacja, porozumienia, uzgodnienia i konsultacje. Obok nich występują tradycyjne formy władcze ${ }^{20}$.

13 J. Boć, T. Kuta, Prawo administracyjne, cz. 1, Wrocław 1980, s. 131.

14 A. Błaś, Proces administrowania jako zorganizowany układ działań administracji publicznej, Wrocław 1972, s. 85 n.

15 Ibidem, s. 85.

16 Ibidem, s. 90.

17 A. Błaś, Pojęcie działań złożonych administracji. Studium z metodologii badań nad działaniami administracji, mps, Wrocław 1977, s. 239, cyt. za: J. Boć, T. Kuta, op. cit., s. 132.

18 T. Kuta, Czy działania złożone administracji publicznej sq herezja prawnicza??, [w:] Prawo administracyjne w okresie transformacji..., s. 70.

19 Ibidem.

20 Ibidem, s. 72. 
Nie bez powodu przybliżone pokrótce koncepcje traktuje jako wzajemnie się uzupełniające i tworzące spójny zamysł teoretycznoprawny, który znajduje zastosowanie w naukach prawnych.

\section{Ciąg działań w naukach prawych oraz orzecznictwie}

Do przedstawionych koncepcji współcześnie wielokrotnie odwołują się przedstawiciele innych dziedzin prawa niż publiczne prawo gospodarcze, a także sądy.

W prawie administracyjnym materialnym Jan Zimmermann w ramach klasyfikacji form działania wprowadza pojęcie „ciąg działań administracyjnych”, to jest podejmowania przez organy administracji w jednej sprawie wielu działań zmierzających do jednego celu ${ }^{21}$. Także Marek Wierzbowski i Aleksandra Wiktorowska wskazują, że ,niejednokrotnie rozwiązanie problemu czy sprawy wymaga zastosowania kolejno działań administracji, mających różne formy prawne. Mówi się wtedy o ciągu działań prawnych lub działaniach złożonych administracji”"22.

Z kolei Andrzej Wasilewski, analizując zasady prewencji oraz przezorności obowiązujące na gruncie prawa ochrony środowiska, stwierdził, że

W celu umożliwienia efektywnego urzeczywistniania treści obu wymienionych zasad prawnych, w których wyrażona została w istocie ogólna dyrektywa postępowania, nakazująca unikanie zachowań, mogących spowodować pogorszenie stanu środowiska (in dubio pro securitate), na gruncie współczesnego prawodawstwa w bogatym arsenale administracyjnoprawnych instrumentów ochrony środowiska, obok klasycznych materialno- i formalnoprawnych środków lub form prawnych działania, pojawiły się również nowe rozwiązania prawne, które charakteryzują się głównie tym, że: bądź nawiązują wprawdzie do ujęć tradycyjnych (np. aktu administracyjnego lub jurysdykcyjnego postępowania administracyjnego), ale ich nie odwzorowują, bowiem z uwagi na przedmiot i cele tej regulacji poddawane są zwykle niezbędnej adaptacji, a przyjmują kształt złożonego ciągu czynności lub działań prawnych ${ }^{23}$.

Najczęściej do teorii ciągu działań czy działań złożonych sięga się przy opisywaniu funkcji administracji świadczącej ${ }^{24}$. W prawie administracyjnym proce-

21 J. Zimmermann, Prawo administracyjne, Kraków 2006, s. 283. Podobnie: B. Kowalczyk, Prawne formy działania administracji publicznej. Konspekt wyktadu, mps, grudzień 2015, s. 1; oraz $A B C$ administracji, red. S. Fundowicz, P. Śwital, M. Wieczorek, Radom 2013, s. 11.

22 A. Wiktorowska, M. Wierzbowski, Prawne formy działania administracji, [w:] Prawo administracyjne, red. M. Wierzbowski, Warszawa 2009, s. 267.

23 A. Wasilewski, Dynamika zmian i kontynuacja we współczesnym prawie administracyjnym wyzwaniem dla doktryny prawa (na przykładzie prawa o ochronie środowiska), [w:] Między tradycja a przyszłościq w nauce prawa administracyjnego. Księga jubileuszowa dedykowana Profesorowi Janowi Bociowi, red. J. Supernat, Wrocław 2009, s. 774.

24 Szerzej zob. R. Stasikowski, Funkcja administracji świadczacej, „Administracja: Teoria, Dydaktyka, Praktyka" 2009, nr 3 (16), s. 89-115; I. Sierpowska, Pomoc społeczna jako administracja świadcząca. Studium administracyjnoprawne, Warszawa 2012, s. 347 n.; oraz S. Nitecki, Prawo do pomocy społecznej w polskim systemie prawnym, Warszawa 2008, s. 305.

Prawo 329, 2020

(C) for this edition by CNS 
sowym pojęcie zorganizowanego ciągu działań służy najczęściej określeniu postępowania administracyjnego w szerokim ujęciu tego słowa ${ }^{25}$.

Do koncepcji ciągu działań odwołują się też cywiliści, analizując kompetencje walnego zgromadzenia w sprawach dotyczących podwyższenia kapitału i objęcia akcji. Wskazują, że walne zgromadzenia inicjuje jedynie uchwalę o podwyższeniu kapitału. Natomiast umowa objęcia akcji stanowi przesłankę ważności czynności konwencjonalnych ${ }^{26}$. Ciągiem działań nazywa się także proces cywilny, który ,jawi się jako mechanizm złożony z ciągu czynności, które są w istocie momentami wyboru jednego $\mathrm{z}$ dwóch możliwych rozwiązań: pożądanego podjęcia działań albo zaniechania, które spotyka się z wyraźnymi sankcjami”27.

Z kolei sądy administracyjne koncepcję ciągu działań wykorzystują przeważnie w sprawach dotyczących legalizacji robót budowlanych ${ }^{28}$ albo wymierzenia kary pieniężnej za zajęcie pasa drogowego ${ }^{29}$. NSA w wyroku z dnia 12 października 2016 roku stwierdził, że z

ciągiem działań prawnych mamy do czynienia, gdy jedna decyzja stanowi podstawę do wydania drugiej (innej) decyzji. Natomiast wydanie tej drugiej decyzji nie jest możliwe bez uprzedniego wydania decyzji pierwszej. Owa zależność rozstrzygnięć jest w każdym przypadku analizowana i badana w oparciu o regulacje materialnoprawne. Taka sytuacja ma np. miejsce w odniesieniu do decyzji o pozwoleniu na użytkowanie ${ }^{30}$.

\section{Ciąg działań w publicznym prawie gospodarczym}

Koncepcja ciągu działań w publicznym prawie gospodarczym jest przedmiotem licznych analiz. Dochodzenie do konkluzji, że w danym wypadku mamy do czynienia z ciągiem działań, oparte jest jednak na różnych metodach badawczych. Co do zasady można wyodrębnić dwie — metodę opartą głównie na analizie przepisów postępowania zmierzającego do określonego prawem celu oraz metodę dotyczącą analizy funkcji administracji publicznej.

25 B. Adamiak, Zagadnienia ogólne procesowego prawa administracyjnego, [w:] System Prawa Administracyjnego, red. R. Hauser, Z. Niewiadomski, A. Wróbel, t. 9. Prawo procesowe administracyjne, Warszawa 2010, s. 3.

26 T. Sójka, Umowa objęcia akcji, Warszawa 2012, s. 137.

27 M. Gościniak, Proces cywilny jako ciag czynności procesowych, http://repozytorium.uni. wroc.pl/Content/89456/01_05_M_Gosciniak_Postepowanie_cywilne_jako_ciag_czynnosci_procesowych.pdf (dostęp: 20.09.2019).

28 Na przykład wyrok NSA z dnia 10 grudnia 2014 roku, sygn. II OSK 1287/13, http://orzeczenia.nsa.gov.pl/doc/612C740AA8 (dostęp: 20.09.2019).

29 Na przykład wyrok WSA w Warszawie z dnia 2 kwietnia 2008 roku, sygn. VI SA/Wa 1724/07, http://orzeczenia.nsa.gov.pl/doc/A1F88A9021 (dostęp: 20.09.2019).

30 Wyrok NSA z dnia 12 października 2016 roku, sygn. II OSK 3322/14, http://orzeczenia.nsa. gov.pl/doc/D83BD28F83 (dostęp: 2.09.2019). 


\subsection{Analiza procedury podejmowania działań}

Na gruncie publicznego prawa gospodarczego sięgnięto po koncepcję ciągu działań prawnych stosunkowo wcześnie, analizując po 1990 roku proces komercjalizacji i prywatyzacji ${ }^{31}$. W tym wypadku zastosowanie koncepcji ciągu działań wydawało się oczywiste wobec relacji zachodzących między organami administracji a przedsiębiorstwem państwowym. Nie oznacza to jednak, że koncepcja ciągu działań czy działań złożonych ma ograniczone zastosowanie. Bez wątpienia koncepcja „działań powiązanych” odnalazła się także w sferze szeroko rozumianej gospodarki komunalnej.

Anna Albin wśród działań gminy organizujących system gospodarowania odpadami komunalnymi wyróżniła, podobnie jak Tadeusz Kuta, fazy: koncepcyjno-przygotowawczą, uchwalenia (zaakceptowania) przygotowanej koncepcji oraz realizacji. Poddając te fazy ocenie, zauważyła, że „cechą charakterystyczną poszczególnych czynności i działań jest ich spójność i ciągłość. Wszystkie są w pewien sposób wzajemnie uwarunkowane i wzajemnie na siebie oddziałują, tworząc w ten sposób uporządkowany tok działań organizujących" ${ }^{32}$. W konkluzji stwierdziła, że „tak stanowienie prawa, jak i stosowanie prawa w obszarze gospodarowania odpadami komunalnymi odbywa się w ciągu zorganizowanego działania. Innymi słowy, zorganizowany ciąg działań odpowiada procesowi gospodarowania odpadami komunalnymi" 33 .

Interesującą koncepcję ciągu działań prawnych i jej wpływu na instytucję partnerstwa publiczno-prywatnego zaprezentowała Bożena Popowska ${ }^{34}$. Rozważając przydatność tej koncepcji w badaniach nad partnerstwem publiczno-prywatnym, autorka uznała za konieczne wzięcie pod uwagę istotnych cech ciągu działań prawnych określonych przez Adama Chełmońskiego. Zdaniem Bożeny Popowskiej w warunkach nowego ustroju taka współpraca podmiotu publicznego i prywatnego jest nieodzowna w celu realizacji zadań administracji publicznej; w szczególności należy wskazać na zadania realizowane w sferze użyteczności publicznej ${ }^{35}$. Kolejnym kryterium poza podmiotowym jest kryterium rozłożenia działań w czasie i ich złożoność przedmiotowa. Na tej podstawie autorka doszła do wniosku, że partnerstwo publiczno-prywatne może być rozpatrywane w konwencji „ciągu dzia-

31 A. Trela, Tryb dokonywania komercjalizacji przedsiębiorstw państwowych, [w:] Prawo wobec wyzwań współczesności, red. P. Wiliński, Poznań 2004, s. 262; oraz A. Monarcha-Matlak, Działania organizacyjne $i$ odpowiedzialność ministra wobec przedsiębiorstwa państwowego, Szczecin 2003, s. 135 n.

32 A. Albin, Gmina w systemie gospodarowania odpadami komunalnymi, Wrocław 2018, s. 231.

33 Ibidem, s. 345.

34 B. Popowska, Partnerstwo publiczno-prywatne w świetle koncepcji ,ciagu działań prawnych" i jej wpływ na ocenę umowy o PPP, [w:] Środki prawne publicznego prawa gospodarczego, red. L. Kieres, Wrocław 2007, s. 159 n.

35 Ibidem, s. 160. 
łań prawnych", a co za tym idzie może być uznane za ciąg działań zamkniętych, albowiem zmierza do pewnego określonego celu, jakim jest realizacja konkretnego przedsięwzięcia ${ }^{36}$. Ciąg działań prawnych, na co słusznie zwraca uwagę autorka, nie daje jednak odpowiedzi na pytanie o charakter prawny związków zachodzących w ramach realizacji partnerstwa publiczno-prywatnego. Wzajemne stosunki między podmiotem publicznym a prywatnym są bowiem kształtowane w sposób szczególny i złożony za pomocą instrumentów publicznoprawych i prywatnoprawnych.

Zdaniem Tadeusza Kocowskiego można założyć,

iż procedura działań prowadzących do udzielenia zamówienia publicznego stanowi, znany w teorii prawa administracyjnego, swoisty ciąg następujących po sobie, powiązanych czynności faktycznych i prawnych, efektem którego ma być nie tyle skorzystanie z autonomii woli przy wyborze przyszłego partnera umowy, ile wybór tego partnera i zawarcie umowy o realizację zamówienia, z zachowaniem przewidzianych przepisami ustawy rozwiązań i zasad wynikających z konieczności uwzględnienia przez zamawiających troski o interes publiczny ${ }^{37}$.

Autor wskazał także liczne czynności składające się na wspomniany ciąg działań, a także zwrócił uwagę, że działania podejmowane w ciągu z założenia są działaniami zamawiającego, co jednak nie wyklucza udziału w tym ciągu także czynności podejmowanych przez inne podmioty ${ }^{38}$.

\subsection{Analiza funkcji administracji}

Rafał Stasikowski, prowadząc rozważania nad rozumieniem funkcji regulacyjnej administracji publicznej, również nawiązał do koncepcji ciągu działań Adama Chełmońskiego i uznał, że

przez funkcję regulacyjną należy rozumieć tę część działalności administracji publicznej, która przybiera postać ciągów działań nakierowanych na realizację dobra wspólnego przez zapewnienie ciągłości i powszechności, jak i również przewidzianej przez prawo jakości (standardów) określonych przepisami prawa usług, świadczonych na rzecz ludności przez podmioty prywatne wykonujące sprywatyzowane zadania publiczne ${ }^{39}$.

Analizując istotę nadzoru, Andrzej Borkowski stwierdził natomiast, że ustalenie stopnia zgodności zachowań przedsiębiorcy z prawem następuje przez podjęcie czynności stanowiącej pierwszy element ciągu działań tworzących nadzór

\section{Ibidem.}

37 T. Kocowski, Kontrola zamówień publicznych, [w:] Kontrola zamówień publicznych, red. T. Kocowski, J. Sadowy, Warszawa 2013, s. 23.

38 Ibidem.

39 R. Stasikowski, Funkcja regulacyjna administracji publicznej. Studium z zakresu nauki prawa administracyjnego oraz nauki administracji, Bydgoszcz-Katowice 2009, s. 175-176. T. Skoczny uznał to podejście za oryginalne, aczkolwiek odosobnione - idem, Regulacja prokonkurencyjna w sektorach infrastrukturalnych, [w:] Prawo konkurencji, t. 15, red. M. Kępiński, mps, Warszawa 2013, s. 11, https://www.cars.wz.uw.edu.pl/tresc/doradztwo/11/Prokonkurencyjne_regulacje_sektorowe_wprowadzenie_do_studenckich_warsztatatow_regulacyjnych.docx (dostęp: 2.09.2019). 
bieżący ${ }^{40}$. Odnosząc się z kolei do pomocy publicznej jako funkcji państwa, przyjął, że „funkcje to zespół następstw, pewien ciąg konsekwencji i skutków społecznych wywoływanych przez działania określonych instytucji (organizacji) w następstwie wykonywania zleconych im normatywnie zadań" 41 .

\subsection{Normatywna koncepcja „wzajemnie powiązanych działań”}

Legalna definicja polityki rozwoju, przez którą rozumie się ,zespół wzajemnie powiązanych działań podejmowanych i realizowanych w celu zapewnienia trwałego i zrównoważonego rozwoju kraju, spójności społeczno-gospodarczej, regionalnej i przestrzennej, podnoszenia konkurencyjności gospodarki oraz tworzenia nowych miejsc pracy w skali krajowej, regionalnej lub lokalnej" 42 , bez wątpienia uzasadniała konfrontację koncepcji ciągu działań prawnych czy działań złożonych z działaniami podejmowanymi w ramach polityki rozwoju.

Dogłębnej analizy tej koncepcji podjęła się Katarzyna Kokocińska, która stwierdziła, że ustawowa konstrukcja prowadzenia polityki rozwoju jako zespołu powiązanych działań wynika zarówno z charakteru zadań publicznych, jak i z szeroko rozumianego celu tej polityki. Są to działania ogólnosystemowe, realizowane na każdym poziomie podziału terytorialnego państwa i przez wszystkie podmioty władzy wykonawczej, co z zasady wymaga współpracy ${ }^{43}$. Współpraca podmiotów prowadzenia polityki rozwoju oparta jest na działaniach podmiotów samodzielcych pomiędzy tymi podmiotami, a w konsekwencji pomiędzy działaniami, jakie podejmują. Autorka dostrzega, że polityka rozwoju dotyczy wzajemnie powiązanych działań podmiotów publicznych, które w strukturze organizacyjno-kompetencyjnej, a przede wszystkim ustrojowej, pozostają niezależne i samodzielne. Ma to z kolei odzwierciedlenie w materii dotyczącej form działania, które zdaniem Katarzyny Kokocińskiej — przez swoistość wyznaczonego celu oraz rozległość skutków działania — powoduje, że instrumenty prawa administracyjnego w ich klasycznej wersji okazują się niewystarczające ${ }^{44}$. „Nadto stosowane przez ustawodawcę [...] instrumenty prawne często abstrahują od ukła-

40 A. Borkowski, Struktura prawna nadzoru nad regulowana działalnościa gospodarcza, „Przegląd Prawa i Administracji” 114, 2018, s. 455.

41 A. Borkowski, Pomoc publiczna jako funkcja państwa wobec społecznej gospodarki rynkowej, ,Przegląd Prawa i Administracji” 103, 2015, s. 14.

42 Ustawa $\mathrm{z}$ dnia 6 grudnia 2006 roku o zasadach prowadzenia polityki rozwoju (tekst jedn. Dz.U. z 2009 r. Nr 84, poz. 712 ze zm.).

${ }^{43}$ K. Kokocińska, Decentralizacja jako ustrojowa zasada relacji pomiędzy organami władzy publicznej, ,Ruch Prawniczy, Ekonomiczny i Socjologiczny” 2016, nr 2, s. 31.

${ }^{44}$ K. Kokocińska, Prawny mechanizm prowadzenia polityki rozwoju $w$ zdecentralizowanych strukturach władzy publicznej, Poznań 2014, s. 264. 
dów organizacyjnych, w których obowiązują, a ich nazewnictwo nie odpowiada doktrynalnym konstrukcjom" 45 .

Autorka zauważa, że właściwe realizacji polityki rozwoju formy działania, takie jak strategie i programy, są wynikiem prawnie uporządkowanego procesu ich przygotowania i przyjmowania. Oryginalność mechanizmu polityki rozwoju wyznacza zakres wspólnych spraw, ustawowy obowiązek osiągania celu publicznego, zorganizowanie proceduralne ${ }^{46}$. Konstrukcja normatywna prowadzenia polityki rozwoju zakłada, że cel publiczny — trwały i zrównoważony rozwój oraz spójność - możliwy jest do osiągniecia przez łączenie działań w większe zespoły tworzące ciąg działań, które mają charakter wzajemnie uzupełniających się i warunkujących zachowań. Ten sposób wykonywania zadań został nazwany przez badaczkę ,publicznoprawnymi działaniami powiązanymi”, które w głównej mierze opierają się na związkach o charakterze ustrojowym ${ }^{47}$.

Warto również odnotować, że w literaturze uważa się, że planowanie traktowane jako element polityki rozwoju, lecz także jako pierwotna i podstawowa funkcja procesu zarządzania ${ }^{48}$, powinno występować wszędzie tam, gdzie działania administracji tworzą złożony ciąg celów, zadań oraz konkretnych czynności ${ }^{49}$. Planowanie jest bowiem traktowane jako pewien ciąg działań faktycznych i prawnych ${ }^{50}$. Wskazuje się też, że działania planistyczne nie wymagają szczególnej podstawy prawnej. Wystarczającą podstawą jest tutaj sama norma zadaniowa, określająca zadania oraz cel działania poszczególnych podmiotów administracji publicznej, co jest jednoznaczne z nałożeniem na ten podmiot prawnego obowiązku wykonania danego zadania lub osiągnięcia wyznaczonego celu ${ }^{51}$.

\section{Pozaprawne uwarunkowania ciągu działań}

Michał Kulesza, nawiązując do koncepcji działań złożonych oraz wyodrębnionej w jej ramach przez Tadeusza Kutę funkcji organizatorskiej, zwrócił uwagę na istotę swobody organizatorskiej. Mianowicie stwierdził, że

w sferze techniki legislacyjnej bywa i tak, że czasem nie odróżnia się nawet tych obszarów regulacji, w których chodzi o stosowanie (wykonywanie) prawa, i tych, których ustanawia się podstawy dla określania celów publicznych i są definiowane sposoby ich osiągania. Tymczasem w dziedzinach,

45 Ibidem.

46 Ibidem, s. 266.

47 K. Kokocińska, Decentralizacja..., s. 34.

48 M. Górski, J. Kierzkowska, Strategie, plany i programy, [w:] System Prawa Administracyjnego, red. R. Hausner, Z. Niewiadomski, A. Wróbel, t. 7. Prawo administracyjne materialne, Warszawa 2012, s. 182.

49 M. Pomykała, Formy prawne planowania strategicznego w systemie bezpieczeństwa państwa, „Przegląd Prawa Publicznego” 2016, nr 9, s. 52.

50 S. Gajewski, Programy rzadowe. Studium administracyjnoprawne, Warszawa 2017, s. 14.

51 J. Zimmermann, op. cit., s. 54. 
gdzie podstawowy jest klasyczny mechanizm stosowania prawa, rządzą najczęściej ustawy szczegółowe, w sferze zaś gospodarki komunalnej rządzi zdrowy rozsądek. Rządzą bowiem potrzeby mieszkańców jako odesłanie pozanormatywne zakotwiczone w normie prawnej ${ }^{52}$.

Autor zdecydowanie opowiada się za kluczowym znaczeniem „swobody organizatorskiej", która stanowi niezbywalny atrybut każdej działalności gospodarczej, także działalności gospodarczej samorządu, podejmowanej w interesie mieszkańców (w interesie wspólnoty samorządowej) i oczywiście „w granicach prawa" 53 . Prawną gwarancję organizatorskiej swobody samorządu w organizowaniu usług publicznych stanowi przy tym art. 7 ust. 1 ustawy z dnia 8 marca 1990 roku o samorządzie gminnym ${ }^{54}$ oraz art. 1 ust. 2 ustawy z dnia 20 grudnia 1996 roku o gospodarce komunalnej ${ }^{55}$. Michał Kulesza wskazywał też, że

jeżeli zaprzeczamy swobodzie organizatorskiej samorządu w zakresie gospodarki komunalnej w szerokim rozumieniu tego pojęcia, to w istocie rzeczy zaprzeczamy samorządowi terytorialnemu, ratio decidendi bowiem przyczyna restytucji w Polsce samorządu terytorialnego była jedna: przekazać odpowiedzialność za zaspokajanie zbiorowych potrzeb mieszkańców samym wspólnotom samorządowym, wyposażonym w samodzielny status w prawie publicznym, w osobowość prawa cywilnego, mienie i inne atrybuty samodzielności prawnej, pozwalającej tę misję realizować „w ramach ustaw", w interesie mieszkańców ${ }^{56}$.

Osobiście dostrzegam ten rodzaj swobody w procesie powierzania zadania z zakresu gospodarki komunalnej ${ }^{57}$. Z kolei Katarzyna Kokocińska upatruje swobodę organizatorską jednostek samorządu terytorialnego także w przepisach ustawy o zasadach prowadzenia polityki rozwoju i zauważa przy tym, że działania obejmujące przygotowanie strategii rozwoju, programów oraz ich realizacji tworzą ciągi działań prawych i organizacyjnych. Co więcej, autorka podkreśla, że na pozaprawne uwarunkowania organizowania świadczenia usług przez jednostki samorządu terytorialnego istotny wpływ wywierają akty polityki władzy wykonawczej. Nie bez znaczenia pozostają w tym względzie również akty organów Unii Europejskiej, na przykład wytyczne KE dotyczące udanego partnerstwa publiczno-prawnego ${ }^{58}$. $\mathrm{Z}$ pewnością podstawową i wiodącą rolę odgrywają $\mathrm{w}$ tej mierze wiążące akty prawa unijnego ${ }^{59}$, określające między innymi tryby współ-

52 M. Kulesza, Gospodarka komunalna — podstawy i mechanizmy prawne, „Samorząd Terytorialny" 2012, $\mathrm{nr} 7-8$, s. 9.

53 Ibidem.

54 Tekst jedn. Dz.U. z 2019 r. poz. 506.

55 Tekst jedn. Dz.U. z 2019 r. poz. 712.

56 M. Kulesza, op. cit., s. 22.

57 A. Trela, Powierzanie zadań z zakresu gospodarki komunalnej a swoboda zawierania umów, „Ruch Prawniczy, Ekonomiczny i Socjologiczny” 2015, nr 3, s. 250.

${ }^{58}$ Guidelines for Successful Public-Private Partnerships, opublikowane przez KE w marcu 2013 roku, s. 13.

59 Rozporządzenie Parlamentu Europejskiego i Rady (UE) Nr 1303/2013 z dnia 17 grudnia 2013 roku ustanawiające wspólne przepisy dotyczące Europejskiego Funduszu Rozwoju Regionalnego, Europejskiego Funduszu Społecznego, Funduszu Spójności, Europejskiego Funduszu Rolnego na rzecz Rozwoju Obszarów Wiejskich oraz Europejskiego Funduszu Morskiego i Rybackiego oraz ustanawiające przepisy ogólne dotyczące Europejskiego Funduszu Rozwoju Regionalnego, 
działania oparte na stosunkach dwustronnych. Mam tu na myśli akty konsensualne, takie jak umowę partnerstwa czy kontrakt terytorialny.

Natomiast na gruncie regulacji Wojciech Szydło zwrócił uwagę, że część działań organów administracji realizowana jest poza ramami sformalizowanych procedur administracyjnych. Chodzi tu o tak zwaną instytucję przyrzeczeń Prezesa Urzędu Komunikacji Elektronicznej, polegających na uprzednim uzgodnieniu decyzji z przedsiębiorcą. Zjawisko to nosi nazwę koregulacji, polegającej na tym,

że organy publiczne wraz z podmiotami prywatnymi współdziałają ze sobą w określony sposób w wypracowaniu oraz nadaniu mocy wiążącej określonym regulacjom, porządkując działalność określonego sektora i sterując działalnością określonych przedsiębiorstw w celu urzeczywistnienia interesu publicznego ${ }^{60}$.

\section{Autor zauważył też, że}

działalność administracyjna, w tym regulacyjna, jest przecież bardzo złożonym ciągiem rozmaitych działań, na które składają się bardzo różne działania faktyczne oraz prawne, a wśród nich jurysdykcyjne postępowania administracyjne stanowią tylko pewien element ${ }^{61}$.

\section{Wnioski}

W publicznym prawie gospodarczym sięgamy do koncepcji ciągu działań czy działań złożonych rzeczywiście w sytuacji, kiedy realizacja zadania publicznego wymaga podjęcia zespołu działań, rozłożonych w czasie, które przybierają nie tylko różną formę prawną (w tym nieznaną dotychczas), lecz także ich charakter prawny pozostaje często niedookreślony. Metoda normowania stosunków prawnych składających się na ciąg działań bywa bowiem bardzo złożona. Przeważnie dotyczy to powiązań zachodzących pomiędzy czynnościami regulowanymi metodą administracyjnoprawną oraz czynnościami regulowanymi metodą cywilnoprawną. W publicznym prawie gospodarczym nie ma jednego typowego ciągu działań prawnych. Ciągi działań są wielopoziomowe w warstwie ustrojowej, materialnoprawnej i proceduralnej. Nie są to proste relacje opierające się na działaniach organ-przedsiębiorca. Ciągi działań w publicznym prawie gospodarczym wymagają współdziałania nawet kilku podmiotów, także organów UE (mam tu na myśli ciągi działań występujące w prawie pomocy publicznej czy prawie konkurencji). Jednym normatywnie wyodrębnionym ciągiem działań są działania wzajemnie powiązanych określone przepisami ustawy o zasadach prowadzenia polityki rozwoju.

Europejskiego Funduszu Społecznego, Funduszu Spójności i Europejskiego Funduszu Morskiego i Rybackiego oraz uchylające rozporządzenie Rady (WE) nr 1083/2006 (Dz.Urz. UE L 347/320).

60 W. Szydło, Charakter prawny nieformalnych uzgodnień administracyjnych pomiędzy Prezesem Urzędu Komunikacji Elektronicznej a przedsiębiorca telekomunikacyjnym i ich sądowa kontrola, „Prace Naukowe Uniwersytetu Ekonomicznego we Wrocławiu” 495, 2017, s. 137.

61 Ibidem, s. 133. 


\section{Bibliografia}

ABC administracji, red. S. Fundowicz, P. Śwital, M. Wieczorek, Radom 2013.

Adamiak B., Zagadnienia ogólne procesowego prawa administracyjnego, [w:] System Prawa Administracyjnego, red. R. Hauser, Z. Niewiadomski, A. Wróbel, t. 9. Prawo procesowe administracyjne, Warszawa 2010.

Albin A., Gmina w systemie gospodarowania odpadami komunalnymi, Wrocław 2018.

Błaś A., Pojęcie działań złożonych administracji. Studium z metodologii badań nad działaniami administracji, mps, Wrocław 1977.

Błaś A., Proces administrowania jako zorganizowany układ działań administracji publicznej, Wrocław 1972.

Boć J., Kuta T., Prawo administracyjne, cz. 1, Wrocław 1980.

Borkowski A., Pomoc publiczna jako funkcja państwa wobec społecznej gospodarki rynkowej, „Przegląd Prawa i Administracji” 103, 2015.

Borkowski A., Struktura prawna nadzoru nad regulowana działalnościa gospodarcza, „Przegląd Prawa i Administracji” 114, 2018.

Chełmoński A., Ciag działań w gospodarce jako przedmiot badań - propozycje metodologiczne, Wrocław 1972.

Chełmoński A., Przedsiębiorstwo państwowe wobec organów zwierzchnich, Wrocław 1966.

Gajewski S., Programy rzadowe. Studium administracyjnoprawne, Warszawa 2017.

Górski M., Kierzkowska J., Strategie, plany i programy, [w:] System Prawa Administracyjnego, red. R. Hausner, Z. Niewiadomski, A. Wróbel, t. 7. Prawo administracyjne materialne, Warszawa 2012.

Gościniak M., Proces cywilny jako ciag czynności procesowych, http://repozytorium.uni.wroc.pl/ Content/89456/01_05_M_Gosciniak_Postepowanie_cywilne_jako_ciag_czynnosci_procesowych.pdf.

Kocowski T., Kontrola zamówień publicznych, [w:] Kontrola zamówień publicznych, red. T. Kocowski, J. Sadowy, Warszawa 2013.

Kokocińska K., Decentralizacja jako ustrojowa zasada relacji pomiędzy organami władzy publicznej, „Ruch Prawniczy, Ekonomiczny i Socjologiczny” 2016, nr 2.

Kokocińska K., Prawny mechanizm prowadzenia polityki rozwoju $w$ zdecentralizowanych strukturach władzy publicznej, Poznań 2014.

Kowalczyk B., Prawne formy działania administracji publicznej. Konspekt wykładu, mps, grudzień 2015.

Kulesza M., Gospodarka komunalna - podstawy i mechanizmy prawne, „Samorząd Terytorialny” 2012, nr 7-8.

Kuta T., Aspekty prawne działań administracji publicznej w organizowaniu uslug, Wrocław 1969.

Kuta T., Czy działania złożone administracji publicznej sq herezja prawnicza??, [w:] Prawo administracyjne w okresie transformacji ustrojowej, red. E. Knosala, A. Matan, G. Łaszczyca, Kraków 1999.

Monarcha-Matlak A., Działania organizacyjne i odpowiedzialność ministra wobec przedsiębiorstwa państwowego, Szczecin 2003.

Nitecki S., Prawo do pomocy społecznej w polskim systemie prawnym, Warszawa 2008.

Pomykała M., Formy prawne planowania strategicznego $w$ systemie bezpieczeństwa państwa, „Przegląd Prawa Publicznego” 2016, nr 9.

Popowska B., Partnerstwo publiczno-prywatne $w$ świetle koncepcji „ciagu działań prawnych” i jej wplyw na ocene umowy o PPP, [w:] Środki prawne publicznego prawa gospodarczego, red. L. Kieres, Wrocław 2007. 
Rabska T., Działania administracji publicznej w świetle wspótczesnej koncepcji publicznego prawa gospodarczego, [w:] Instrumenty i formy prawne działania administracji gospodarczej, red. B. Popowska, K. Kokocińska, Poznań 2009.

Sierpowska I., Pomoc społeczna jako administracja świadczaca. Studium administracyjnoprawne, Warszawa 2012.

Skoczny T., Regulacja prokonkurencyjna w sektorach infrastrukturalnych, [w:] Prawo konkurencji, t. 15, red. M. Kępiński, mps, Warszawa 2013, https://www.cars.wz.uw.edu.pl/tresc/doradztwo/11/Prokonkurencyjne_regulacje_sektorowe_wprowadzenie_do_studenckich_warsztatatow_regulacyjnych.docx.

Sobczak K., Płaszczyzny zależności między władza publiczna i gospodarka, [w:] Prawo administracyjne w okresie transformacji ustrojowej, red. E. Knosala, A. Matan, G. Łaszczyca, Kraków 1999.

Sójka T., Umowa objęcia akcji, Warszawa 2012.

Stasikowski R., Funkcja administracji świadczacej, „Administracja: Teoria, Dydaktyka, Praktyka” 2009, nr 3 (16).

Stasikowski R., Funkcja regulacyjna administracji publicznej. Studium z zakresu nauki prawa administracyjnego oraz nauki administracji, Bydgoszcz-Katowice 2009.

Szydło W., Charakter prawny nieformalnych uzgodnień administracyjnych pomiędzy Prezesem Urzędu Komunikacji Elektronicznej a przedsiębiorca telekomunikacyjnym i ich sądowa kontrola, „Prace Naukowe Uniwersytetu Ekonomicznego we Wrocławiu” 495, 2017.

Trela A., Powierzanie zadań z zakresu gospodarki komunalnej a swoboda zawierania umów, „Ruch Prawniczy, Ekonomiczny i Socjologiczny” 2015, nr 3.

Trela A., Tryb dokonywania komercjalizacji przedsiębiorstw państwowych, [w:] Prawo wobec wyzwań współczesności, red. P. Wiliński, Poznań 2004.

Wasilewski A., Dynamika zmian i kontynuacja we wspótczesnym prawie administracyjnym wyzwaniem dla doktryny prawa (na przyktadzie prawa o ochronie środowiska), [w:] Między tradycja a przyszłościq w nauce prawa administracyjnego. Księga jubileuszowa dedykowana Profesorowi Janowi Bociowi, red. J. Supernat, Wrocław 2009.

Wiktorowska A., Wierzbowski M., Prawne formy działania administracji, [w:] Prawo administracyjne, red. M. Wierzbowski, Warszawa 2009.

Zimmermann J., Prawo administracyjne, Kraków 2006.

\section{The concept of a series of legal actions in public economic law (selected issues)}

\section{Summary}

The author characterises the concept of a series of legal actions indicating its basic features and application in the legal sciences. He supplements this concept with a "set of implementing actions" and "idea of complex actions in administration", recognising that they form a coherent concept, which is reflected in a number of actions taken under public economic law.

Keywords: series of legal actions, legal forms of action, complex actions, organization of services, interrelated activities. 